\title{
Trace metal content in sediment cores and seagrass biomass from a tropical southwest Pacific Island
}

\author{
Shalini Singh ${ }^{\text {a,b,*, Monal M. Lal }}{ }^{\text {c,d }}$, Paul C. Southgate ${ }^{c}$, Morgan Wairiu ${ }^{a}$, Awnesh Singh ${ }^{a}$ \\ ${ }^{a}$ Pacific Centre for Environment and Sustainable Development, The University of the South Pacific, Lower Laucala Campus, Laucala Bay Road, Suva, Fiji \\ ${ }^{\mathrm{b}}$ College of Agriculture, Fisheries and Forestry, Fiji National University, Koronivia, Nausori, Fiji \\ ${ }^{\mathrm{c}}$ Australian Centre for Pacific Islands Research and School of Science, Technology and Engineering, University of the Sunshine Coast, Maroochydore, Queensland 4558, \\ Australia \\ d Division of Marine Studies, School of Agriculture, Geography, Environment, Ocean and Natural Sciences, University of the South Pacific, Lower Laucala Campus, \\ Laucala Bay Road, Suva, Fiji
}

\section{A R T I C L E I N F O}

\section{Keywords:}

Halophila ovalis

Halodule pinifolia

Halodule uninervis

Trace metal

Seagrass

Sediment

\begin{abstract}
A B S T R A C T
A unique feature of seagrass among other ecosystem services is to have high phytoremediation potential that is a cost-effective plant-based approach and environmentally friendly solution for metal contamination in coastal areas. The goal of this study was to assess the phytoremediation prospective of seagrass for $\mathrm{Cu}, \mathrm{Fe}, \mathrm{Mn}$ and $\mathrm{Zn}$ in Fiji Islands. Heavy metal content was measured in sediments and tissues of the seagrasses Halophila ovalis, Halodule pinifolia and Halodule uninervis to test for local-scale differences. The local study shows that metal concentration in sediment and seagrass tissue was significantly variable, regardless of species and sediment type. Sedimentary concentration of $\mathrm{Cu}, \mathrm{Fe}, \mathrm{Mn}$ and $\mathrm{Zn}$ obtained in the present study seemed to be lower than that of previous studies. The results support that $H$. ovalis is a good bioindicator species since it accumulated up to 5-fold more of these metals compared to the Halodule species.
\end{abstract}

\section{Introduction}

Seagrasses play a critical role in the ecology of shallow-marine ecosystems where they stabilize sediment, have an important role in global carbon and nutrient cycling, and may function as a long-term biogeochemical sink for trace metals (Duarte, 1999; Serrano et al., 2016). Their life history characteristics, together with their above ground and below ground biomass support their use as biomonitoring species. As seagrass meadows are exposed to stronger anthropogenic pressures than many other marine communities (Ambo-Rappe et al., 2011), trace element levels in seagrass beds can be a useful indicator for harmful pollutants in such ecosystems. Seagrasses are a primary food for many animals (e.g., green turtles and rabbit fish) and metals sequestered by them may be transferred to higher trophic level consumers (Amado Filho et al., 2004).

Previous research has established that marine angiosperms generally have a high trace metal bioaccumulation capacity because of direct interaction from the water column and sediments in the marine environment via both leaves and root-rhizomes that are sites for ionic uptake
(Ambo-Rappe et al., 2011; Bonanno and Di Martino, 2017). A range of pollutants including heavy metals and pesticides (Bonanno et al., 2020) may significantly contaminate inshore seagrass meadows. This is generally a consequence of environmental pollution in coastal areas, which are most productive marine zones and important sinks of anthropogenic contaminants (Bonanno and Orlando-Bonaca, 2018). Thus, seagrasses are often considered as sentinel species because any change in their distribution (e.g. a loss of covered area) implies an environmental change (Govers et al., 2014; Bonanno and Di Martino, 2017).

Unlike pesticides and acid rain, trace metals exist naturally via weathering and erosion of rocks and soils in marine environments; these include copper $(\mathrm{Cu})$, iron $(\mathrm{Fe})$, manganese $(\mathrm{Mn})$ and zinc $(\mathrm{Zn})$, which are essential micronutrients and critical to support plant metabolism (Boutabia-Trea et al., 2017). The same elements may have toxic effects at high concentrations (Bonanno and Di Martino, 2017). Other, nonessential elements are toxic to organisms even at low levels (e.g., $\mathrm{Al}$, As, $\mathrm{Cd}, \mathrm{Cr}, \mathrm{Hg}$ and $\mathrm{Pb}$ ) are highly toxic (Bonanno et al., 2020). Trace metals such as $\mathrm{Cu}$ and $\mathrm{Zn}$ are primarily mobilized through human

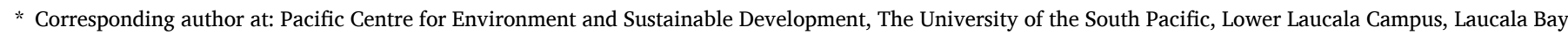
Road, Suva, Fiji.

E-mail address: sophie.shalinisingh@gmail.com (S. Singh).
} 
activity such as urban and municipal runoff, industrial effluents, atmospheric deposition, and agricultural activity, whereas other metals such as Fe and Mn have a lithogenic origin (Serrano et al., 2011). Trace metal research with seagrasses has acknowledged their role as effective biomonitors because their tissue metal content often reflects bio-available water or sediment contents (Sanchiz et al., 2001; Ralph et al., 2006). From a management perspective, it is important to know which species are able to accumulate or concentrate specific metals, because different populations of the same species within small geographical distributions, can have widely different tolerances to metal impacts (Ralph et al., 2006). Toxic levels of metals inhibit metabolic activity and interfere with vital pathways, such as photosynthesis (Ralph and Burchett, 1998). Furthermore, plants that survive, do so with decreased growth and slower development (Clijsters and Van-Assche, 1985).

Trace metal contamination in estuarine seagrass meadows has been identified across the world with most studies from the Mediterranean (Bonanno et al., 2020; Morroni et al. 2020), Caribbean (Govers et al., 2014) and Indian subcontinent (Immaculate et al., 2018) and Australia (Prange and Dennison, 2000). However, similar research in the south Pacific region is lacking. In the Fiji Islands, seagrass beds have been identified as an important marine ecosystem (McKenzie and Yoshida, 2020). However, the coastal environments of Fiji are also facing problem of heavy metal pollution (Maata and Singh, 2008). To our knowledge, there is no existing information on the trace metal contents of intertidal seagrasses in Fiji despite a number of studies that have assessed environmental levels of a number of hazardous metals in coastal sediments, seawater and shellfish (e.g., Gangaiya et al., 2001; Morrison et al., 2001; Maata and Singh, 2008; Arikibe and Prasad, 2020). Similarly, Chand et al. (2010) reported levels of metalloid arsenic in surficial sediments to be $334 \mathrm{mg} / \mathrm{kg}$ (dry weight) which is almost 30 times greater than the $\mathrm{U}$. S. EPA (2004) cleanup guideline level.

More recently, Pratap et al. (2020) reported that the spatial distribution of metals (Cd, Cr, Cu, Fe, Ni, $\mathrm{Pb}$ and $\mathrm{Zn}$ ) in surficial sediments in Laucala Bay, near Suva, was affected by hydrodynamic regimes. This study confirmed that apart from $\mathrm{Cd}$ and $\mathrm{Pb}$, other metals had a medium risk of toxicity, but had a high probability of accumulation and increasing concentration in the near future. Generally, all these studies perceived metal input into Suva coastal area from different sources such as land-based industrial activities like metal fabrication and construction, paint-manufacturing, petroleum storage and garment manufacturing, food processing, sewage treatment plants, as well as direct discharge of domestic and industrial wastes. Overall, it can be noted that factors such as increased economic development, rise in population and urbanization are the major driving forces behind the various anthropogenic sources of heavy metals in the Fijian coastal environment (Pratap et al., 2020). In the Fiji Islands, five species of seagrass from two families (Hydrocharitaceae and Cymodoceaceae) have been reported (Singh et al., 2019).

The few studies on seagrasses in Fiji for example, have focused on morphology, taxonomy and biological/faunal interactions as reported by Singh et al. (2019). We chose to focus on Halodule uninervis, Halodule pinifolia and Halophila ovalis as they are widely distributed throughout the main island coastline (Singh et al., 2019). Brief descriptions of the morphological characteristics of the Halodule plants are identified based on shape of the leaf tip (trident or rounded) and width of the leaves which is either narrow or wide (Den Hartog, 1970). H. pinifolia is often found in the high intertidal to upper subtidal areas, forming homogeneous patches or intermixes with $H$. uninervis and $H$. ovalis (McKenzie and Yoshida, 2020). H. uninervis is found from intertidal to $6 \mathrm{~m}$ depth, forming dense or patchy beds as well as intermixes with other species including $H$. pinifolia, Halophila spp. and Syringodium isoetifolium (McKenzie and Yoshida, 2020). Halophila plants are minute and fragile, without stripe-like long leaf blades, but rather oval shaped leaves in pairs and it is the most diverse seagrass group (Kuo, 2020). H. ovalis is found in the intertidal to 10-12 m depth, forming dense or patchy beds (McKenzie and Yoshida, 2020). Moreover, species of both the genus
Halodule and Halophila grow in shallow intertidal to subtidal waters directly adjacent to coastal areas in sand/mud banks.

In Fiji comparative investigation, using sediment and seagrass has yet not been examined as a biomonitoring tool for coastal trace metal contamination and deserve investigation to provide reliable data on marine environmental health. As heavy metal contamination is a great concern at the global, regional and local level because they are not able to be degraded and the toxic effects can be long lasting (Gangaiya et al., 2001). While seagrasses are known as good bioindicators as, they are widespread and sensitive to environmental changes and are able to integrate ecological conditions and processes over various timescales from weeks to years (Govers et al., 2014).

Therefore, we studied potential trace metal pollution in seagrasses on a local scale to test whether it was possible to detect local-scale differences in trace metal concentrations in both sediments and seagrass plants. Copper, iron, manganese and zinc were selected for this investigation because these metals ( $\mathrm{Cu}, \mathrm{Fe}, \mathrm{Mn}$ and $\mathrm{Zn}$ ) have been recognized as historical contaminants of Laucala Bay (Morrison et al., 2001). For some of the other heavy metals (As, $\mathrm{Cd}, \mathrm{Hg}$, and $\mathrm{Pb}$ ) it was not possible with the resources available to detect concentrations found in samples.

This study was therefore carried out to provide the first report of metal contents in intertidal vegetated sediments and seagrass biomass along the Fijian coast. The aims of the study were to: (i) determine for the first time, contents of four trace metals ( $\mathrm{Cu}, \mathrm{Fe}, \mathrm{Mn}$ and $\mathrm{Zn}$ ) in three tropical seagrass species (H. ovalis, $H$. pinifolia and $H$. uninervis) at two sites; (ii) examine the relationship between metal contents and their environmental compartments (sediments and seagrass tissue); and (iii) reveal any species-specific metal accumulation patterns and identify seagrass species capable of accumulating specific metals.

\section{Materials and methods}

\subsection{Study area}

The study was conducted at Nasese, Suva $\left(18^{\circ} 9^{\prime} 28^{\prime \prime} \mathrm{S}, 178^{\circ} 26^{\prime} 47^{\prime \prime} \mathrm{E}\right)$ and Korotogo, Sigatoka $\left(18^{\circ} 10^{\prime} 12^{\prime \prime} \mathrm{S}, 177^{\circ} 31^{\prime} 53^{\prime \prime} \mathrm{E}\right)$, along the southern coast of Viti Levu, Fiji Islands (Fig. 1). The climate of Fiji may be categorised as an oceanic tropical marine climate with annual rainfall ranging from 1800 to $2600 \mathrm{~mm}$ (Singh et al., 2019). The average air temperature is $25^{\circ} \mathrm{C}$ but ranges from $18{ }^{\circ} \mathrm{C}$ to $30^{\circ} \mathrm{C}$ in summer months. The islands have distinct wet and dry zones, with the former located in the southeast region of Viti Levu, while the north and west are usually drier. The dry season is from May to October, the wet season from November to April, and tides are generally diurnal with an annual mean tidal range of $1.1 \mathrm{~m}$. The mean range of neap tides is $0.9 \mathrm{~m}$ and spring tides is $1.3 \mathrm{~m}$, and inshore sea surface temperatures have an annual average of between $24^{\circ} \mathrm{C}$ to $31^{\circ} \mathrm{C}$.

Surveys were conducted near the two largest river systems in the Fiji Islands, the Rewa River and Sigatoka River located on the southern coast of Viti Levu (Fig. 1). The Rewa River empties into Laucala Bay through the Vunidawa River. The shoreline along the eastern side of Laucala Bay is largely covered by mangroves, and has a wide intertidal zone composed of very fine-grained mud, silt and sand from five relatively smaller rivers (Pohler and Collen, 2006). Situated along the coastline on the eastern side of the Sigatoka River, Korotogo has a wide fringing reef flat interrupted by a narrow channel.

At each location, sampling was performed within intertidal areas in seagrass meadows dominated by either $H$. uninervis, $H$. pinifolia or $H$. ovalis, as well as unvegetated areas adjacent to the seagrass study site. Sampling locations were chosen at random and only the top $10 \mathrm{~cm}$ of sediment was analyzed in this analysis. Because previous work (Pohler and Collen, 2006) had indicated that sediments in the area were predominantly mud ( $<63 \mu \mathrm{g}$ factor is $\geq 90 \%$ ), so no specific particle analysis was completed. 


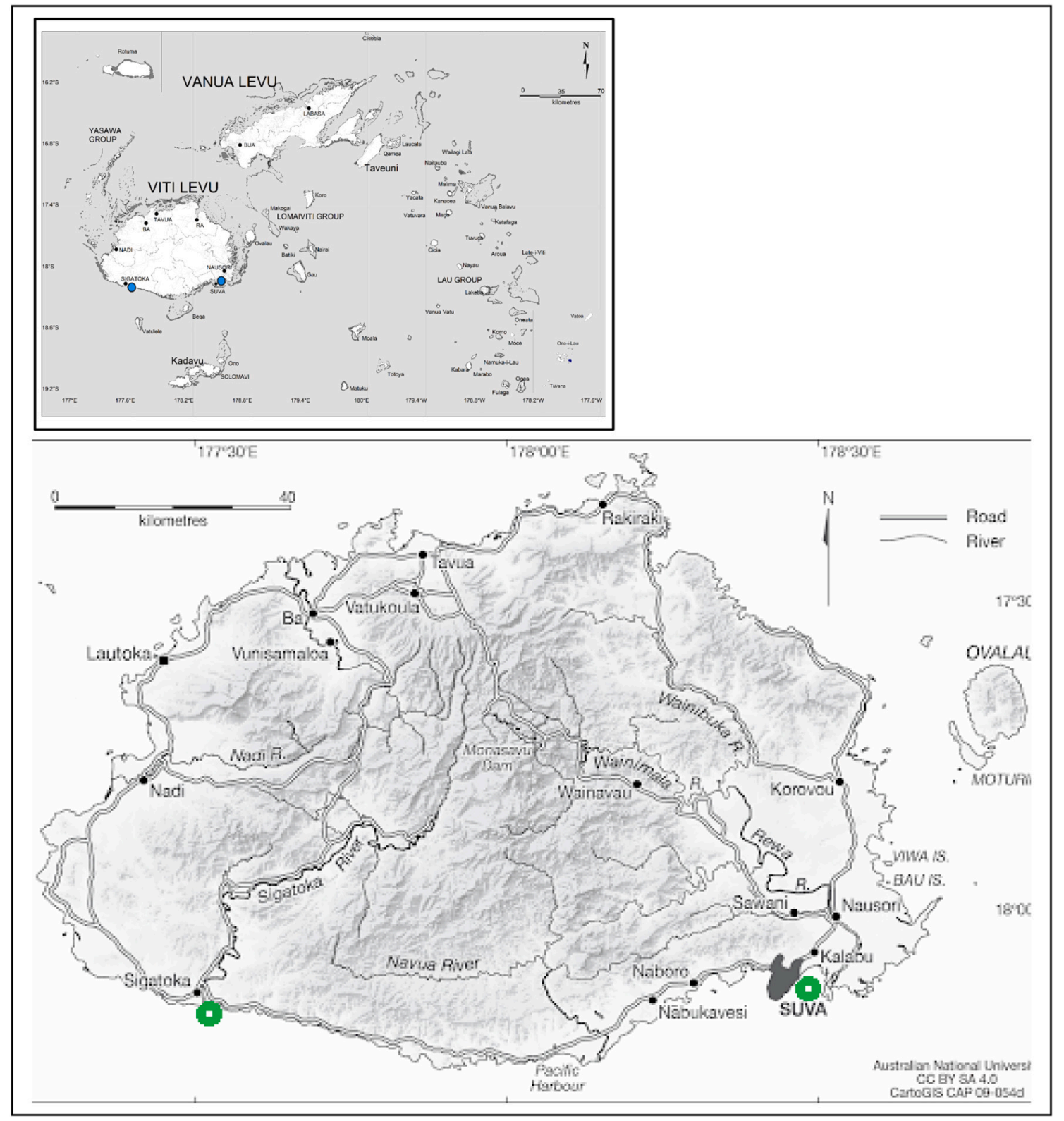

Fig. 1. Map of the Fiji Islands showing the two study sites located in the southeast (Rewa River) and southwest (Sigatoka River) of Viti Levu. Source: The map base layer has been adapted from Lal et al. (2016) and CartoGIS Services Maps Online Australian National University.

\subsection{Sediments and tissue sample collection}

The fieldwork was conducted in the peak growth period in summer season (November 2017 to February 2018), during which were collected seagrass plants and sediments at Nasese in Laucala Bay, Suva, and Korotogo in Sigatoka. Sites were geolocated in the field using a handheld GPS unit (Garmin eTrex10). The geographical coordinates for each station at the two sites are reported in Supplementary material, Table S1. These sites were distributed along the coastlines and at depths ranging from 0.1 to $0.5 \mathrm{~m}$. We examined $\mathrm{Cu}, \mathrm{Fe}, \mathrm{Mn}$ and $\mathrm{Zn}$ content along all sediment cores and within seagrass tissue. Sampling was conducted using a linear transect and quadrant $(50 \mathrm{~cm} \times 50 \mathrm{~cm})$ method to obtain sediments and plant tissue within each quadrant (Kim et al., 2017). The seagrass habitats of $H$. uninervis $(\mathrm{n}=15), H$. pinifolia $(\mathrm{n}=15)$ and $H$. ovalis $(\mathrm{n}=15)$ were the dominate species present at all sampling sites.

To ensure that specimen records are traceable, sample collection data including GPS coordinates, taxonomic information and photographic images recorded during field collections were uploaded to the
Barcoding of Life Data (BOLD) system repository (http://www.boldsy stems.org) (Singh et al., 2019). This enabled the provision of support for identifications, and permitted easier comparisons between species (Singh et al., 2019).

Sampling at each location was carried out by selecting 15 stations every $5 \mathrm{~m}$ along a shore-perpendicular transect line method described by standard Seagrass-Watch methods (http://www.seagrasswatch.org). Within each station, three replicate sediment cores $(\sim 2-5 \mathrm{~m}$ apart) were collected at different positions within the quadrant targeting top $10 \mathrm{~cm}$ of sediment, from both inside the meadow and an adjacent unvegetated area. The top $10 \mathrm{~cm}$ of sediment was within the depth range influenced by root growth (Greiner et al., 2013), and hence analyses were restricted to this layer as the focus of this study was trace metal content within the upper zone. Cores of sediment were sampled at low tide by manually inserting PVC pipe (30 cm length, $5 \mathrm{~cm}$ internal diameter) into the substrate. A total of 360 sediment cores and 45 quadrats were sampled to cover all areas of seagrass distribution within 160 ha of the coastal locations. 
Sediment samples of known volumes were picked free of living plant tissue and stored in labelled Ziploc ${ }^{\circledR}$ bags and transported to the laboratory for further processing on the same day. In the laboratory, the sediment was cleaned of larger shells, in-fauna, and plant material before drying (Gullström et al., 2018). Sediments were dried at $60^{\circ} \mathrm{C}$ for $48 \mathrm{~h}$ until a constant weight was achieved and homogenized (Govers et al., 2014).

For the collection of plant biomass in each quadrant, all aboveground (leaves and stems) and belowground vegetation (rhizomes and roots) were harvested to a vertical depth of $10 \mathrm{~cm}$. Seagrasses were dug from the substrate, cleaned in seawater to remove accompanying debris, and transported in labelled Ziploc ${ }^{\circledR}$ plastic bags to the laboratory. Epiphytes were removed by gently scarping seagrass leaves with a microscope slide. We saw no sign of herbivory (bite or grazing marks) in the collected leave samples. Cleaned seagrass tissue was dried at $60{ }^{\circ} \mathrm{C}$ to a constant weight for $48 \mathrm{~h}$ (Govers et al., 2014). Dried seagrass material was weighed to determine the dry weight of individual species. Dry samples of each species were pooled within each replicate and homogenized in preparation for trace metal analysis. We measured $\mathrm{Cu}, \mathrm{Fe}, \mathrm{Mn}$ and $\mathrm{Zn}$ contents of the sediments and whole plant biomass of the three seagrass species. In addition, bioaccumulation factors (BAF) for each species and trace metal element was calculated using the method described by Lewis and Devereux (2009), which is BAF = concentration in seagrass/concentration in water or sediment (Table 2).

Trace metal concentrations, obtained from Fiji's Great Astrolabe lagoon (Maata and Singh, 2008) were used to compare the trace metal concentrations in Nasese and Korotogo sediment and whole plant samples. The Great Astrolabe lagoon is far from anthropogenic influence and is considered here as a pristine and uncontaminated site, hence, can be used for comparison of heavy metals for studies in Fiji (Maata and Singh, 2008). Iron and manganese were not determined in the Astrolabe lagoon work. Moreover, the value for $I_{\text {geo }}$ was calculated using Eq. (1), where $C_{n}$ is the concentration of the heavy metal $(n)$ measured while $B_{n}$ is the geochemical background concentration of that particular heavy metal (n) (Muller, 1969). By using the Great Astrolabe value, the geoaccumulation index was calculated. $\mathrm{I}_{\text {geo }}$ comprises seven different classes (Table S3).

$\mathrm{I}_{\text {geo }}=\log _{2}\left[\mathrm{C}_{\mathrm{n}} / 1.5 \mathrm{~B}_{\mathrm{n}}\right]$

\subsection{Copper, Iron, manganese and zinc extraction}

The extraction method of Lindsay and Norvell (1978), which uses diethylenetriaminepentaacetic acid (DTPA) was used to assess $\mathrm{Cu}, \mathrm{Fe}$, $\mathrm{Mn}$ and $\mathrm{Zn}$ contents of sediment samples. In brief, sediment samples weighing $10 \mathrm{~g}$ were digested in $20 \mathrm{ml}$ of extracting reagent (double strength reagent - 0.005 M DTPA, $0.01 \mathrm{M}$ calcium chloride and $0.1 \mathrm{M}$ TEA) and centrifuged at $2000 \mathrm{rpm}$ for $15 \mathrm{~min}$. The solution was filtered using a Whatman nucleopore polycarbonate track-etch membrane filter paper, which has a diameter of $42 \mathrm{~mm}$ and porosity of $0.4 \mu \mathrm{m}$ (Merck $\mathrm{KGaA}$ ). The metal content ( $\mathrm{Cu}, \mathrm{Fe}, \mathrm{Mn}$, and $\mathrm{Zn}$ ) in sediments and whole plant tissues were determined using an atomic absorption spectrometer (AAS - Pekin Elmer ${ }^{\circledR}$, Pinaacle 900F).

The method used for analysis of plant tissues was described by Prasad and Spiers (1978), and involved dry ashing the plant samples (1 g) for $4 \mathrm{~h}$ at $475{ }^{\circ} \mathrm{C}$, then grinding to a powder. Dried plant materials were digested with hydrochloric acid $(5 \mathrm{ml})$ and gently heated for approximately $20 \mathrm{~min}$. The residue was then made up to a $50 \mathrm{ml}$ solution volume using distilled water after filtering through No. 42 Whatman filter paper, and then metal concentrations $(\mathrm{Cu}, \mathrm{Fe}, \mathrm{Mn}$ and $\mathrm{Zn})$ were determined using an atomic absorption spectrometer (AAS - Pekin Elmer®). All analyses were carried out at the chemistry laboratory of the Koronivia Research Station, Ministry of Agriculture in Fiji.

The quality checking was verified through analytical blanks and stability of instrumental recalibration (Bonanno et al., 2020). Analyses were conducted in triplicates and method detection limits were employed in order to justify the reliability and validity of the method used. In addition, percent recovery for all the metals analyzed was within the acceptable range of 90 and $100 \%$. Based on the standard error given by supplier, our results fell within the acceptable range $(95 \%$ confidence interval). Wavelengths used for analysis of each metal using the atomic absorption spectrometer are provided in Supplementary material, Table S2.

\subsection{Data analysis}

\subsubsection{Descriptive statistics}

Exploratory data analysis was carried out to check the variability and distribution of each variable: $\mathrm{Cu}, \mathrm{Fe}, \mathrm{Mn}, \mathrm{Zn}$ and sites. All data were tested for homogeneity of variances and normality with Levene's and Shapiro-Wilk tests, respectively, and where necessary Box-Cox transformed to conform to the assumptions of ANOVA. We assume that high between-site variability is a signal of prevalent local sources of contamination. Testing for differences in the variables studied among communities, meadows and sites was determined using a two-way fixed factor ANOVA. Tukey's HSD (honest significant difference) test was performed to distinguish differences among and between seagrass plant tissues and sediment. Confidence intervals (95\%) and $p$-values obtained for the ANOVA and Tukey's tests were used to consider differences in sediments and seagrass species. Because sites were distributed across three meadows, models included both community and meadow as direct effects, along with their interaction. All statistics were performed using $\mathrm{R}$ statistical software version 3.6.3 ( $\mathrm{R}$ Core Team, 2020) using the following packages: basic, car, and mass.

\section{Results}

We assessed trace metal contents of seagrasses as an indicator of their level of pollution in coastal areas and their bioavailability in seagrass tissues and sediments. Measurement of trace metals in sediment provided a standard for metal loads in the area, while seagrass tissue content reflects longer-term trace metal accumulation (Govers et al., 2014). Significant variation $(p<0.05)$ was recorded for the levels of trace metals in sediment and seagrass tissues with the latter consistently displaying high contents of all trace metals determined in this study (Table 5; Figs. 2-5). Iron (Fe) was identified as having the highest element concentration affecting sediments in seagrass meadows at both sites, with it being accumulated most in seagrass tissue. While, Mn had the second highest element level observed in both sediments and tissues of the three seagrass species. In contrast, $\mathrm{Cu}$ and $\mathrm{Zn}$ were considered the least accumulated anthropogenic pollutant in both sediment and seagrass tissue. Mean values $( \pm \mathrm{SD}$ ) and trends in the levels of each metal in both sediments and whole plant tissue are summarized in Table 1.

Seagrass bioaccumulation factor values (BAF) displayed wide variation between seagrass species and are impacted by physical, chemical and biological factors (Lewis and Devereux, 2009; Table 2). This indicates that $H$. ovalis concentrated more trace metals than $H$. pinifolia and $H$. uninervis based on bioaccumulation factor values when comparing whole plant-sediment values obtained for $\mathrm{Cu}, \mathrm{Fe}, \mathrm{Mn}$ and $\mathrm{Zn}$. $H$. ovalis had a higher than anticipated trace metal content between 1 and 5-fold (Table 2) for all metals. In contrast, differences in $\mathrm{Cu}, \mathrm{Fe}, \mathrm{Mn}$ and $\mathrm{Zn}$ content in $\mathrm{H}$. pinifolia and $\mathrm{H}$. uninervis were less than 1.3-fold.

$\mathrm{I}_{\text {geo }}$ values were calculated for $\mathrm{Cu}$ and $\mathrm{Zn}$ elements only and reported in Table 3. On the other hand, Fe and Mn were not determined in Astrolabe lagoon work, thus are not calculated and included in the table. The $\mathrm{I}_{\text {geo }}$ values for $\mathrm{Cu}$ and $\mathrm{Zn}$ from the two sites were mostly within $0-1$, which were assigned to be no to moderately contaminated. Results indicated that Korotogo was mostly contaminated with higher levels of $\mathrm{Cu}$ and $\mathrm{Zn}$ than compared to Nasese, which are mostly introduced into the coastal environments by anthropogenic means. This might be mainly because the area have been quite urbanized and industrialized with construction and hotel developments that could be contributing source 

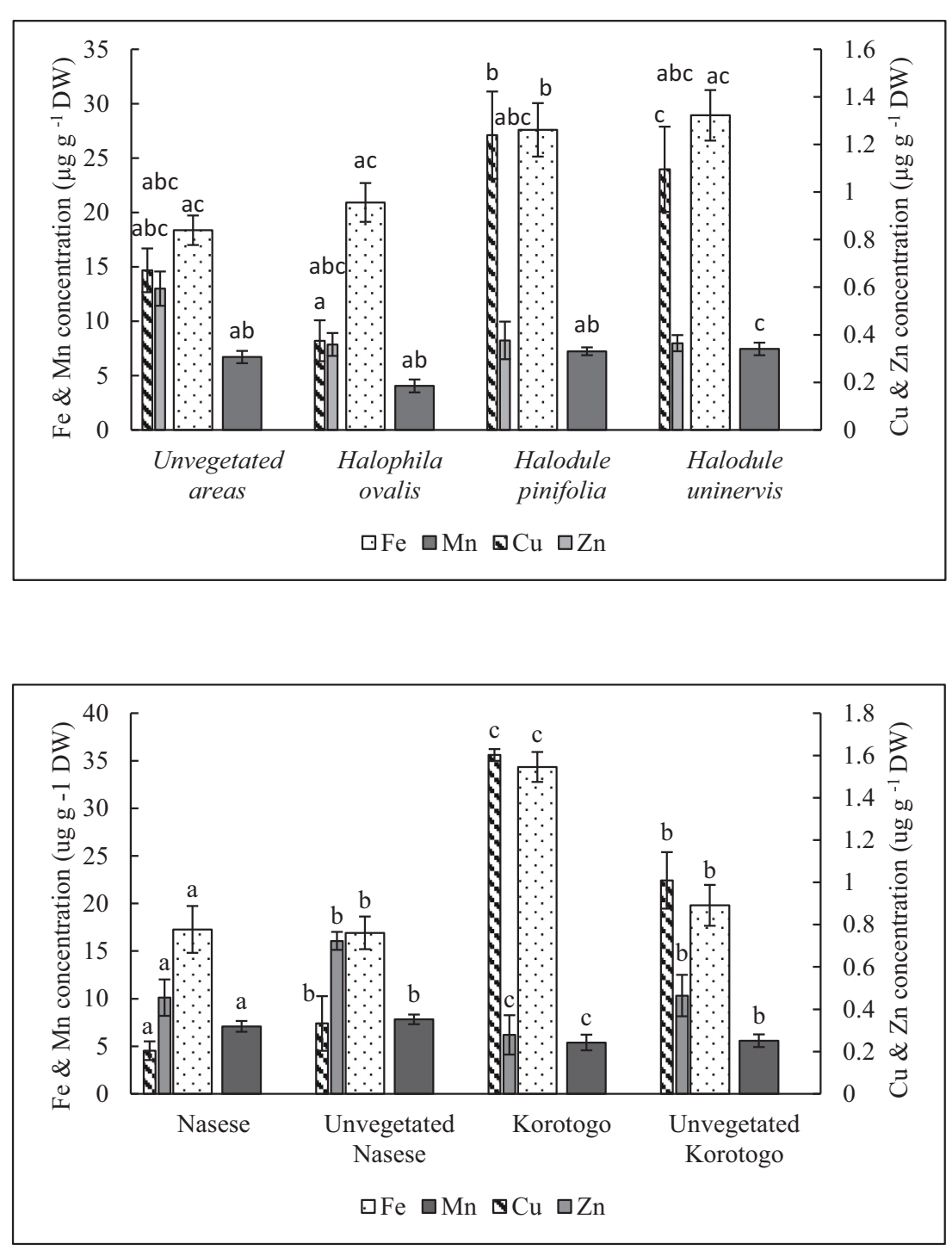

Fig. 2. Mean ( \pm SE) trace metal content ( $\mu g^{-1}$ dry weight) in sediments in seagrass meadows (with seagrasses separated at the species/genus level) and unvegetated areas pooled. Copper and zinc content in sediment are presented on the secondary vertical (right) axis for reference. The trace metal values are based on a sediment depth of $10 \mathrm{~cm}$. The trace element levels of each sample type vary significantly across vegetated and unvegetated sites; to show this, for each sample type, different letters per different seagrass beds were used; Tukey's test, $\alpha=0.001$.
Fig. 3. Mean ( \pm SE) trace metal content ( $\mu \mathrm{g} \mathrm{g}^{-1}$ dry weight) in sediments for seagrass meadows (with the three seagrasses, that is, Ho, Hp, and Hu sp., merged; for seagrass name abbreviations, see Fig. 2) and unvegetated areas from two Fijian sites. The trace metal values are derived from pooled seagrass meadows and unvegetated areas to a sediment depth of $10 \mathrm{~cm}$. Copper and zinc contents of sediment are presented on the secondary vertical (right) axis for reference. The trace element levels of each sample type vary significantly across vegetated and unvegetated sites; to show this, for each sample type, different letters per different sites were used; Tukey's test, $\alpha=$ 0.001 .

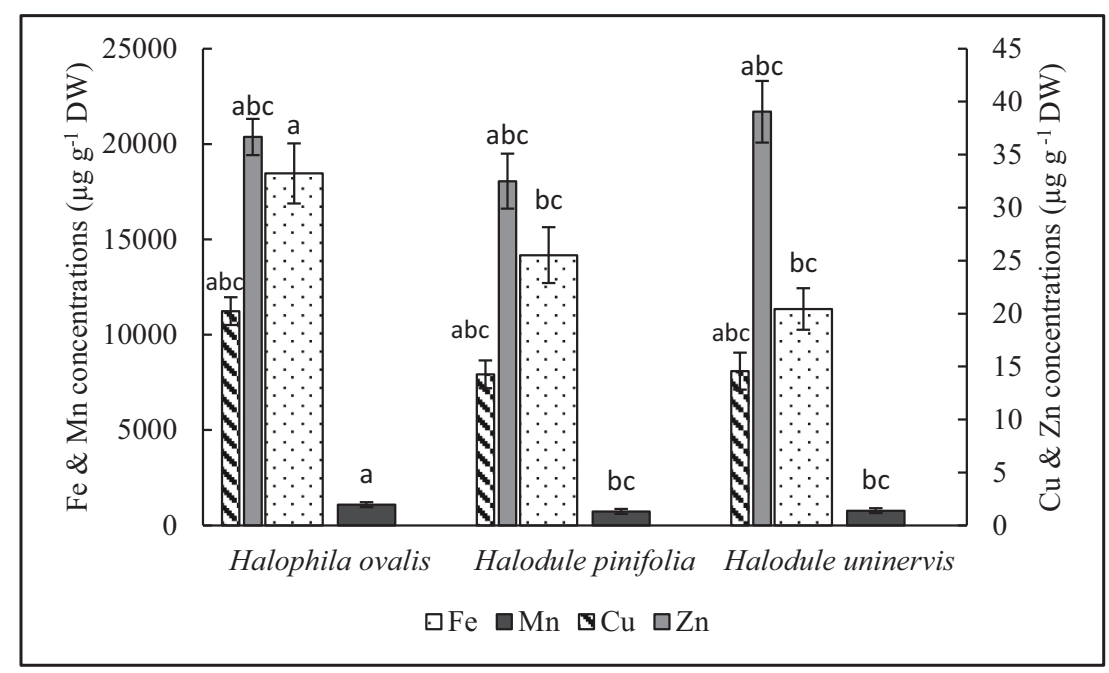

Fig. 4. Mean ( \pm SE) trace metal content ( $\mu \mathrm{g} \mathrm{g}^{-1}$ dry weight) in seagrasses species meadows from two Fijian sites. Copper and zinc contents of sediment are presented on the secondary vertical (right) axis for reference. The trace element levels of each sample type vary significantly across species; to show this, for each sample type, different letters per different seagrass species were used; Tukey's test, $\alpha=0.001$. 


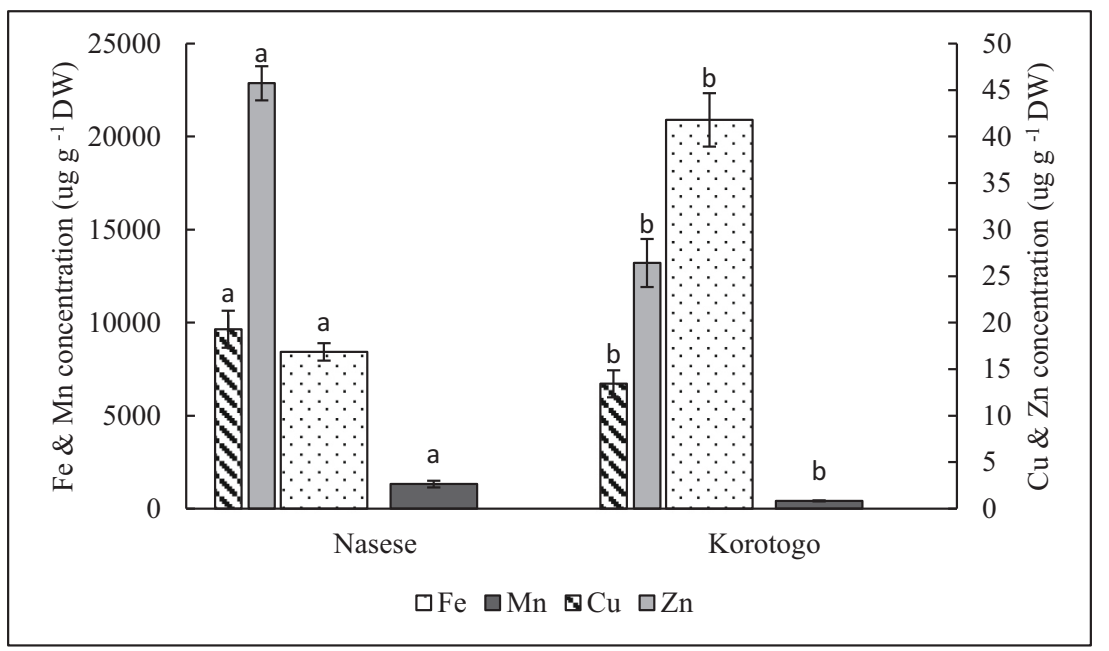

Fig. 5. Mean $\left( \pm\right.$ SE) trace metal content ( $\mu \mathrm{g} \mathrm{g}^{-1}$ dry weight) in seagrasses species meadows from two Fijian sites. Copper and zinc contents of sediment are presented on the secondary vertical (right) axis for reference. The trace element levels of each sample type vary significantly across the two sites; to show this, for each sample type, different letters per different site were used; Tukey's test, $\alpha=0.001$.

Table 1

Mean $\left( \pm\right.$ SD) trace metal contents ( $\mu \mathrm{g} \mathrm{g}^{-1}$ dry wt.) of sediments and seagrass species. Sediment values are at depth of $10 \mathrm{~cm}$ for the combined 15 plots for both study sites.

\begin{tabular}{|c|c|c|c|c|c|c|c|c|c|c|}
\hline \multirow{2}{*}{$\begin{array}{l}\text { Study site } \\
\text { Habitat }\end{array}$} & \multicolumn{5}{|c|}{ Sediment } & \multicolumn{5}{|l|}{ Plant } \\
\hline & $\mathrm{Cu}$ & $\mathrm{Fe}$ & Mn & $\mathrm{Zn}$ & Trend & $\mathrm{Cu}$ & $\mathrm{Fe}$ & Mn & $\mathrm{Zn}$ & Trend \\
\hline \multicolumn{11}{|l|}{ Nasese } \\
\hline Halophila ovalis & $\begin{array}{l}0.11 \pm \\
0.09\end{array}$ & $\begin{array}{l}15.02 \pm \\
10.30\end{array}$ & $\begin{array}{l}6.84 \pm \\
2.29\end{array}$ & $\begin{array}{l}0.36 \pm \\
0.28\end{array}$ & $\begin{array}{l}\mathrm{Cu}<\mathrm{Zn}<\mathrm{Mn} \\
<\mathrm{Fe}\end{array}$ & $\begin{array}{l}20.33 \pm \\
6.65\end{array}$ & $\begin{array}{l}10,782.93 \pm \\
2191.02\end{array}$ & $\begin{array}{l}1329.27 \pm \\
920.96\end{array}$ & $\begin{array}{l}42.27 \pm \\
8.00\end{array}$ & $\begin{array}{l}\mathrm{Cu}<\mathrm{Zn}<\mathrm{Mn} \\
<\mathrm{Fe}\end{array}$ \\
\hline $\begin{array}{l}\text { Halodule } \\
\text { pinifolia }\end{array}$ & $\begin{array}{l}0.32 \pm \\
0.33\end{array}$ & $\begin{array}{l}17.93 \pm \\
9.95\end{array}$ & $\begin{array}{l}7.55 \pm \\
2.38\end{array}$ & $\begin{array}{l}0.60 \pm \\
0.52\end{array}$ & $\begin{array}{l}\mathrm{Cu}<\mathrm{Zn}<\mathrm{Mn} \\
<\mathrm{Fe}\end{array}$ & $\begin{array}{l}17.07 \pm \\
6.06\end{array}$ & $\begin{array}{l}7493.07 \pm \\
2146.90\end{array}$ & $\begin{array}{l}1251.13 \pm \\
685.60\end{array}$ & $\begin{array}{l}42.67 \pm \\
6.50\end{array}$ & $\begin{array}{l}\mathrm{Cu}<\mathrm{Zn}<\mathrm{Mn} \\
<\mathrm{Fe}\end{array}$ \\
\hline $\begin{array}{l}\text { Halodule } \\
\text { uninervis }\end{array}$ & $\begin{array}{l}0.17 \pm \\
0.09\end{array}$ & $\begin{array}{l}18.89 \pm \\
8.32\end{array}$ & $\begin{array}{l}6.87 \pm \\
1.92\end{array}$ & $\begin{array}{l}0.40 \pm \\
0.20\end{array}$ & $\begin{array}{l}\mathrm{Cu}<\mathrm{Zn}<\mathrm{Mn} \\
<\mathrm{Fe}\end{array}$ & $\begin{array}{l}20.47 \pm \\
10.42\end{array}$ & $\begin{array}{l}7005.60 \pm \\
1098.98\end{array}$ & $\begin{array}{l}1380.87 \pm \\
497.21\end{array}$ & $\begin{array}{l}52.27 \pm \\
6.82\end{array}$ & $\begin{array}{l}\mathrm{Cu}<\mathrm{Zn}<\mathrm{Mn} \\
<\mathrm{Fe}\end{array}$ \\
\hline $\begin{array}{l}\text { Unvegetated } \\
\text { area }\end{array}$ & $\begin{array}{l}0.33 \pm \\
0.11\end{array}$ & $\begin{array}{l}16.92 \pm \\
6.09\end{array}$ & $\begin{array}{l}7.82 \pm \\
3.18\end{array}$ & $\begin{array}{l}0.72 \pm \\
0.36\end{array}$ & $\begin{array}{l}\mathrm{Cu}<\mathrm{Zn}<\mathrm{Mn} \\
<\mathrm{Fe}\end{array}$ & & & & & \\
\hline \multicolumn{11}{|l|}{ Korotogo } \\
\hline Halophila ovalis & $\begin{array}{l}0.64 \pm \\
0.54\end{array}$ & $\begin{array}{l}26.81 \pm \\
3.91\end{array}$ & $\begin{array}{l}1.25 \pm \\
0.56\end{array}$ & $\begin{array}{l}0.36 \pm \\
0.24\end{array}$ & $\begin{array}{l}\mathrm{Zn}<\mathrm{Cu}<\mathrm{Mn} \\
<\mathrm{Fe}\end{array}$ & $\begin{array}{l}20.13 \pm \\
7.66\end{array}$ & $\begin{array}{l}26,137.00 \pm \\
5123.15\end{array}$ & $\begin{array}{l}852.87 \pm \\
204.99\end{array}$ & $\begin{array}{l}31.07 \pm \\
6.99\end{array}$ & $\begin{array}{l}\mathrm{Cu}<\mathrm{Zn}<\mathrm{Mn} \\
<\mathrm{Fe}\end{array}$ \\
\hline $\begin{array}{l}\text { Halodule } \\
\text { pinifolia }\end{array}$ & $\begin{array}{l}2.15 \pm \\
0.48\end{array}$ & $\begin{array}{l}37.26 \pm \\
8.73\end{array}$ & $\begin{array}{l}6.91 \pm \\
1.38\end{array}$ & $\begin{array}{l}0.15 \pm \\
0.10\end{array}$ & $\begin{array}{l}\mathrm{Zn}<\mathrm{Cu}<\mathrm{Mn} \\
<\mathrm{Fe}\end{array}$ & $\begin{array}{l}11.47 \pm \\
7.14\end{array}$ & $\begin{array}{l}20,861.33 \pm \\
5891.36\end{array}$ & $\begin{array}{l}266.33 \pm \\
73.20\end{array}$ & $\begin{array}{l}22.33 \pm \\
12.46\end{array}$ & $\begin{array}{l}\mathrm{Cu}<\mathrm{Zn}<\mathrm{Mn} \\
<\mathrm{Fe}\end{array}$ \\
\hline $\begin{array}{l}\text { Halodule } \\
\text { uninervis }\end{array}$ & $\begin{array}{l}2.02 \pm \\
0.47\end{array}$ & $\begin{array}{l}38.97 \pm \\
7.28\end{array}$ & $\begin{array}{l}8.02 \pm \\
3.95\end{array}$ & $\begin{array}{l}0.32 \pm \\
0.15\end{array}$ & $\begin{array}{l}\mathrm{Zn}<\mathrm{Cu}<\mathrm{Mn} \\
<\mathrm{Fe}\end{array}$ & $\begin{array}{l}8.67 \pm \\
2.09\end{array}$ & $\begin{array}{l}15,700.00 \pm \\
5672.34\end{array}$ & $\begin{array}{l}175.20 \pm \\
39.79\end{array}$ & $\begin{array}{l}25.83 \pm \\
10.58\end{array}$ & $\begin{array}{l}\mathrm{Cu}<\mathrm{Zn}<\mathrm{Mn} \\
<\mathrm{Fe}\end{array}$ \\
\hline $\begin{array}{l}\text { Unvegetated } \\
\text { area }\end{array}$ & $\begin{array}{l}1.01 \pm \\
0.52\end{array}$ & $\begin{array}{l}19.81 \pm \\
8.32\end{array}$ & $\begin{array}{l}5.58 \pm \\
2.58\end{array}$ & $\begin{array}{l}0.46 \pm \\
0.38\end{array}$ & $\begin{array}{l}\mathrm{Zn}<\mathrm{Cu}<\mathrm{Mn} \\
<\mathrm{Fe}\end{array}$ & & & & & \\
\hline
\end{tabular}

Table 2

Bioaccumulation factor (BAF) values and ratios for trace metal content $\left(\mu \mathrm{g} \mathrm{g}^{-1}\right.$ dry weight) in the seagrasses. BAF values were calculated based on Lewis and Devereux (2009).

\begin{tabular}{lllll}
\hline \multirow{2}{*}{ Species } & \multicolumn{4}{l}{ Ratio (conc. seagrass/conc. sediment) } \\
\cline { 2 - 5 } & $\mathrm{Cu}$ & $\mathrm{Fe}$ & $\mathrm{Zn}$ & $\mathrm{Mn}$ \\
\hline Halophila ovalis & 4.7 & 2.3 & 1.2 & 2.6 \\
Halodule pinifolia & 1.0 & 1.3 & 1.0 & 1.0 \\
Halodule uninervis & 1.2 & 1.0 & 1.2 & 1.0 \\
\hline
\end{tabular}

of $\mathrm{Cu}$ and $\mathrm{Zn}$ in the coastal environment. While it is not possible at this stage to fully explain these patterns, they do provide a means of distinguishing between the samples.

The results obtained for the trace metals in seagrass bed sediments were also compared to the results of other studies in Indo-Pacific region as shown in Table 4. The concentration of $\mathrm{Cu}, \mathrm{Fe}, \mathrm{Mn}$ and $\mathrm{Zn}$ obtained in the present study seemed to be lower than that of previous studies. When compared to the pristine environment i.e., the Great Astrolabe Reef in
Table 3

Geo-accumulation index ( $\mathrm{I}_{\mathrm{geo}}$ ) for the studied metals at the two sites. Background concentration of metals used in this study is from the Great Astrolabe reef in Kadavu, Fiji; Fe and Mn were not determined.

\begin{tabular}{lll}
\hline Site/habitat & $\mathrm{Cu}$ & $\mathrm{Zn}$ \\
\hline Nasese & & \\
Halophila ovalis & 0.0008 & 0.0024 \\
Halodule pinifolia & 0.0022 & 0.0041 \\
Halodule uninervis & 0.0011 & 0.0027 \\
$\quad$ Unvegetated area & 0.0022 & 0.0049 \\
Korotogo & & \\
Halophila ovalis & 0.0043 & 0.0025 \\
Halodule pinifolia & 0.0150 & 0.0010 \\
Halodule uninervis & 0.0140 & 0.0022 \\
$\quad$ Unvegetated area & 0.0071 & 0.0031 \\
Background value & 29.6 & 29.5 \\
\hline
\end{tabular}

Kadavu, the concentrations of all metals analyzed at both sites are quite low. This is mainly because the plants absorb the seagrass bed metal elements. Since, seagrasses show different element accumulation 
Table 4

Comparison of the sedimentary trace metal contents $\left(\mu \mathrm{g} \mathrm{g}^{-1}\right)$ in Nasese and Korotogo with other studies done in the Indo-Pacific region.

\begin{tabular}{|c|c|c|c|c|c|}
\hline Study site & $\mathrm{Cu}$ & $\mathrm{Fe}$ & Mn & $\mathrm{Zn}$ & Reference \\
\hline Nasese & $0.11-0.32$ & $15.02-18.89$ & $6.84-7.55$ & $0.36-0.60$ & Present study \\
\hline Korotogo & $0.64-2.15$ & $26.81-38.97$ & $1.25-8.02$ & $0.15-0.36$ & \\
\hline Laucala Bay & $44.2-170$ & $13,733-68,492$ & - & $15.5-15.7$ & Pratap et al., 2020 \\
\hline Great Astrolabe reef & $22-88$ & - & - & $10-164$ & Morrison and Naqasima, 1999 \\
\hline Rewa River & $4.5-6.0$ & $2200-7800$ & - & $5.5-584$ & Deo, 2000 \\
\hline Lami & $5-1980$ & - & - & $52-514$ & Gangaiya et al., 2001 \\
\hline Suva Harbour & $21.4-143$ & $14,000-48,700$ & - & $40.2-269$ & Maata and Singh, 2008 \\
\hline Tonga & $2-180$ & $1550-114,000$ & - & $6-208$ & Morrison and Brown, 2003 \\
\hline Kiribati & $0.3-13.9$ & - & - & $1.2-77$ & Redfern, 2006 \\
\hline New Zealand & $14-48$ & - & - & $97-896$ & Redfern, 2006 \\
\hline India & 214.4 & $3600-34,600$ & $70-818$ & $41-184$ & Mishra et al., 2020 \\
\hline China & $18.23-69.34$ & - & $519.25-1212.79$ & $71.32-143.64$ & Ahamad et al., 2020 \\
\hline
\end{tabular}

Table modified from Pratap et al. (2020).

patterns among the two study sites (Tables 1-3); they may act as biological filters, favoring the decrease of metals.

\subsection{Variability of sedimentary and plant $\mathrm{Cu}$}

Seagrass habitats had higher mean Cu content $\left(0.90 \pm 0.10 \mu \mathrm{g} \mathrm{g}^{-1}\right)$ than nearby unvegetated habitats $\left(0.67 \pm 0.09 \mu \mathrm{g} \mathrm{g}^{-1}\right)$ at both sites (Fig. 2). The mean $\mathrm{Cu}$ content in seagrass sediment ranged from 0.01 to $3.35 \mu \mathrm{g} \mathrm{g}^{-1}$ and was up to one and a half times the levels detected in nearby unvegetated sediments $\left(0.20\right.$ to $2.11 \mu \mathrm{g} \mathrm{g}^{-1}$ ) (Fig. 2). When comparing pooled vegetated habitats versus unvegetated areas, $\mathrm{Cu}$ contents were significantly different (Table 5; Fig. 2). The high between sites variability were recorded in $H$. ovalis, $H$. pinifolia and $H$. uninervis beds, while unvegetated sediments did not show significant difference (Table 5). Similarly, when comparing vegetated habitats with unvegetated areas at both sites, there was a significant effect on mean $\mathrm{Cu}$ contents (Table 5; Fig. 2), which was also apparent between Nasese and Korotogo. The results demonstrated that Korotogo vegetated and unvegetated areas stored more $\mathrm{Cu}$ compared to the Nasese vegetated and unvegetated areas (Fig. 3).

The mean Cu content in seagrass plant tissue was $16.36 \pm 0.90 \mu \mathrm{g} \mathrm{g}^{-1}$ and ranged from 3 to $53 \mu \mathrm{g} \mathrm{g}^{-1}$. H. uninervis had the highest mean plant tissue $\mathrm{Cu}$ content (above and below ground combined) of $11-53 \mu \mathrm{g} \mathrm{g}^{-1}$, with a mean of $20.47 \pm 2.69 \mu \mathrm{g} \mathrm{g}^{-1}$. H. ovalis had the second highest mean plant tissue $\mathrm{Cu}$ content of $10-34 \mu \mathrm{g} \mathrm{g}{ }^{-1}$, with a mean of $20.33 \pm$ $1.72 \mu \mathrm{g} \mathrm{g}^{-1}$, while $H$. pinifolia had the lowest mean plant tissue $\mathrm{Cu}$ content of $4-33$, with a mean of $11.47 \pm 1.84 \mu^{-g^{-1}}$ (Fig. 4). There was a significant interaction demonstrated between seagrass species and $\mathrm{Cu}$ content (Table 5; Fig. 4). However, significant differences between the three seagrass species were not apparent. The mean $\mathrm{Cu}$ content in seagrass tissue differed significantly among sites (Table 5; Fig. 5). Moreover, the sedimentary and seagrass tissue $\mathrm{Cu}$ content was highly significant in the two sites in Fiji (Table 5; Fig. 5).

\subsection{Variability of sedimentary and plant Fe}

Seagrass habitats had a higher mean Fe content $(25.81 \pm 1.33 \mu \mathrm{g}$ $\left.\mathrm{g}^{-1}\right)$ than nearby unvegetated habitats $\left(18.36 \pm 1.36 \mu \mathrm{g} \mathrm{g}^{-1}\right)$ at both sites (Fig. 2). The mean Fe content in seagrass sediment ranged from 6.34 to $55.37 \mu \mathrm{g} \mathrm{g}^{-1}$ and was up to one and a half times the content in nearby unvegetated sediments ( 7 to $40 \mu \mathrm{g} \mathrm{g}^{-1}$ ) (Fig. 2). When comparing pooled vegetated habitats versus unvegetated areas, Fe content were significantly different (Table 5; Fig. 2). However, the only significant variability in Fe content was demonstrated in $H$. pinifolia beds between $H$. ovalis, $H$. uninervis and unvegetated sediments compared to the other interactions. When comparing vegetated habitats and unvegetated areas at both sites, there was a significant effect on mean Fe content (Table 5; Fig. 2), which was also apparent between Nasese and Korotogo. Korotogo vegetated and unvegetated areas were found to store more sedimentary $\mathrm{Fe}$ compared to Nasese vegetated and unvegetated areas (Fig. 3).

The mean Fe content in seagrass plant tissue was $1466.32 \pm 860.66$ $\mu \mathrm{g} \mathrm{g}^{-1}$ and ranged from 4467 to $34,668 \mu \mathrm{g} \mathrm{g}^{-1}$. H. ovalis had the highest mean plant tissue Fe content (above and below ground combined) of $15,563-34,668 \mu \mathrm{g} \mathrm{g}^{-1}$, with a mean of $26,137.00 \pm 1322.79 \mu \mathrm{g} \mathrm{g}^{-1}$. H. pinifolia had the second highest mean plant tissue Fe content of

Table 5

Summary of two-way ANOVA and post hoc Tukey's test for the effects of site, unvegetated and vegetated areas, $\mathrm{Cu}, \mathrm{Fe}$, Mn and $\mathrm{Zn}$ on sediments and seagrass tissue of Halophila ovalis, Halodule pinifolia and Halodule uninervis. Bold indicates statistically significant effects at $p \leq 0.05$.

\begin{tabular}{|c|c|c|c|c|c|c|c|c|c|c|c|c|}
\hline & \multicolumn{3}{|l|}{$\mathrm{Cu}$} & \multicolumn{3}{|l|}{$\mathrm{Fe}$} & \multicolumn{3}{|l|}{ Mn } & \multicolumn{3}{|l|}{$\mathrm{Zn}$} \\
\hline & $\mathrm{df}$ & $F$ value & $p$ value & $\mathrm{df}$ & $F$ value & $p$ value & df & $F$ value & $p$ value & df & $F$ value & $p$ value \\
\hline \multicolumn{13}{|l|}{ Sediments } \\
\hline Site & 1 & 105.69 & $<0.001$ & 1 & 37.09 & $<0.001$ & 1 & 270.12 & $<0.001$ & 1 & 11.81 & $<0.001$ \\
\hline Unvegetated * vegetated & 6 & 31.51 & $<0.05$ & 4 & 17.24 & $<0.05$ & 4 & 18.79 & $<0.05$ & 4 & 2.87 & $<0.05$ \\
\hline Ho * unvegetated & 0.19 & & 0.79 & -2.56 & & 0.79 & 0.57 & & 0.74 & 0.23 & & 0.05 \\
\hline$H p$ * Ho & 0.81 & & $<0.01$ & 6.67 & & $<0.01$ & 0.46 & & 0.87 & 0.017 & & 0.99 \\
\hline$H u * H o$ & 1.38 & & $<0.05$ & -2.03 & & 0.95 & 2.95 & & $<0.01$ & 0.04 & & 0.99 \\
\hline$H p$ * unvegetated & -0.43 & & 0.01 & -9.23 & & $<0.05$ & 0.12 & & 0.73 & 0.22 & & 0.08 \\
\hline$H u$ * unvegetated & 0.10 & & 0.98 & -0.52 & & 0.99 & 3.28 & & $<0.0001$ & 0.19 & & 0.36 \\
\hline$H u * H p$ & 0.57 & & $<0.05$ & 11.38 & & $<0.05$ & 2.49 & & 0.0003 & 0.03 & & 0.99 \\
\hline Sample * site & 0.36 & & $<0.001$ & & & & -4.70 & & 0.0000 & -0.18 & & 0.003 \\
\hline \multicolumn{13}{|l|}{ Whole plant samples } \\
\hline Site & 1 & 20.56 & $<0.001$ & 1 & 284.6 & $<0.001$ & 1 & 93.54 & $<0.001$ & 1 & 97.23 & $<0.001$ \\
\hline Seagrass tissue & 3 & 4.09 & $<0.05$ & 3 & 104.7 & $<0.05$ & 3 & 15.98 & $<0.05$ & 3 & 6.32 & $<0.05$ \\
\hline$H o$ * $\mathrm{Hp}$ & -6.06 & & 0.06 & $10,429.36$ & & 0.0000 & 624.46 & & 0.002 & 1.43 & & 0.96 \\
\hline $\mathrm{Ho} * \mathrm{Hu}$ & -5.77 & & 0.08 & 7848.69 & & 0.0000 & -637.99 & & 0.001 & -3.22 & & 0.69 \\
\hline$H p{ }^{*} H u$ & 0.30 & & 0.99 & -2580.67 & & 0.09 & 64.85 & & 0.96 & 6.55 & & 0.04 \\
\hline Sample * site & -5.8 & & 0.0004 & $12,185.49$ & & 0.0000 & -876.21 & & 0.0000 & -15.59 & & 0.0000 \\
\hline
\end{tabular}


$10,568-34,303 \mu \mathrm{g} \mathrm{g}^{-1}$, with a mean of $20,861.33 \pm 1521.14 \mu \mathrm{g} \mathrm{g}^{-1}$, while $H$. uninervis had the lowest of $6628-27,823 \mu \mathrm{g} \mathrm{g}^{-1}$, with a mean of $15,700.00 \pm 1464.59 \mu \mathrm{g} \mathrm{g}^{-1}$ (Fig. 4). There was a significant interaction between seagrass species and Fe content (Table 5; Fig. 4). Significant differences were apparent for $H$. ovalis between $H$. pinifolia and $H$. uninervis, while both $H$. pinifolia and $H$. uninervis did not differ significantly from each other. The mean Fe in seagrass tissue differed significantly among sites (Table 5; Fig. 5). The sedimentary and seagrass tissue Fe content comparison was highly significant in two sites in Fiji (Fig. 5).

\subsection{Variability of sedimentary and plant $M n$}

Seagrass habitats had lower mean Mn content $\left(4.05 \pm 0.59 \mu \mathrm{g} \mathrm{g}^{-1}\right)$ than nearby unvegetated habitats $\left(6.70 \pm 0.57 \mu \mathrm{g} \mathrm{g}^{-1}\right)$ at both sites (Fig. 2). The mean Mn content in seagrass sediment ranged from 0.61 to 15.93, and in nearby unvegetated sediment varied from 1.98 to 17.10 (Fig. 2). When comparing pooled vegetated habitats versus unvegetated areas, Mn content were significantly different (Table 5; Fig. 2). Moreover, significant variability was observed in $H$. uninervis beds between $H$. ovalis, $H$. pinifolia, and bare sediment; whereas no significant difference were demonstrated for $H$. ovalis, $H$. pinifolia, and bare sediments. When comparing vegetated habitats and unvegetated areas across both sites, there was a significant effect on mean Mn storage (Table 5; Fig. 3), which was also apparent between Nasese and Korotogo. Nasese vegetated and unvegetated areas stored more sedimentary Mn compared to Korotogo vegetated and unvegetated areas (Fig. 3).

The mean Mn content in seagrass plant tissue was $869.28 \pm 76.12 \mu \mathrm{g}$ $\mathrm{g}^{-1}$ and ranged from 99 to $3580 \mu \mathrm{g} \mathrm{g}^{-1}$. H. uninervis had the highest mean plant tissue Mn content (above and below ground combined) of $845-2760 \mu \mathrm{g} \mathrm{g}^{-1}$, with a mean of $1380.87 \pm 128.38 \mu \mathrm{g} \mathrm{g}^{-1}$. H. ovalis had the second highest mean plant tissue Mn content of $388-3580 \mu \mathrm{g} \mathrm{g}^{-1}$, with a mean of $1329.27 \pm 237.79 \mu \mathrm{g} \mathrm{g}^{-1}$, while $H$. pinifolia had the lowest mean plant tissue Mn content of 579-3193 $\mu \mathrm{g} \mathrm{g}^{-1}$, with a mean of $1251.13 \pm 177.02 \mu \mathrm{g} \mathrm{g}^{-1}$ (Fig. 2). There was a significant interaction observed between seagrass species and Mn content (Table 5; Fig. 4). Significant differences were apparent for $H$. ovalis and between $H$. pinifolia and $H$. uninervis, while both $H$. pinifolia and $H$. uninervis did not differ significantly from each other. The mean $\mathrm{Mn}$ in seagrass tissue differed significantly among sites (Table 5; Fig. 5). Likewise, the sedimentary and seagrass tissue Mn content was highly significant between two sites in Fiji (Fig. 5).

\subsection{Variability of sedimentary and plant $\mathrm{Zn}$}

Seagrass habitats had lower mean $\mathrm{Zn}$ content $\left(0.37 \pm 0.03 \mu \mathrm{g} \mathrm{g}^{-1}\right)$ than nearby unvegetated habitats $\left(0.59 \pm 0.07 \mu \mathrm{g} \mathrm{g}^{-1}\right)$ at both sites (Fig. 2). The mean $\mathrm{Zn}$ content in seagrass sediment ranged from 0.002 to $2.17\left(\mu \mathrm{g} \mathrm{g}^{-1}\right)$, and in nearby unvegetated sediments it varied from 0.17 to $1.88 \mu \mathrm{g} \mathrm{g}^{-1}$ (Fig. 2). Furthermore, when comparing pooled vegetated habitats versus unvegetated areas, $\mathrm{Zn}$ contents were significantly different (Table 5; Fig. 2). However, significant differences between all the sediment samples were not observed during pairwise comparisons. Meanwhile, when comparing vegetated habitats and unvegetated areas at both sites, there was a significant effect on mean Zn storage (Table 5; Fig. 2), which was also apparent between Nasese and Korotogo. Nasese vegetated and unvegetated areas stored more sedimentary Zn, compared to Korotogo vegetated and unvegetated areas (Fig. 3).

The mean $\mathrm{Zn}$ content of seagrass plant tissue was $36.07 \pm 1.45 \mu \mathrm{g} \mathrm{g}^{-1}$ and ranged from 0.5 to $68 \mu \mathrm{g} \mathrm{g}^{-1}$. H. uninervis had the highest mean plant tissue Zn content (above and below ground combined) of $42-68 \mu \mathrm{g}$ $\mathrm{g}^{-1}$, with a mean of $52.27 \pm 1.76 \mu \mathrm{g} \mathrm{g}^{-1}$. H. pinifolia had the second highest mean plant tissue $\mathrm{Zn}$ content of 33-54, with a mean of $42.67 \pm$ $1.68 \mu \mathrm{g} \mathrm{g}^{-1}$, while $\mathrm{H}$. ovalis had the lowest mean plant tissue $\mathrm{Zn}$ content of 19-47, with a mean of $31.07 \pm 1.80 \mu \mathrm{g} \mathrm{g}^{-1}$ (Fig. 4). There was a significant interaction demonstrated between seagrass species and $\mathrm{Zn}$ content (Table 5; Fig. 4). However, the three seagrass samples failed to differ significantly from each other. The mean $\mathrm{Zn}$ content in seagrass tissue differed significantly among sites (Table 5; Fig. 5). Both sedimentary and seagrass tissue exhibited a highly significant Zn content between the two sites in Fiji (Fig. 5).

\section{Discussion and conclusion}

The trace metals analyzed in this study ( $\mathrm{Cu}, \mathrm{Fe}, \mathrm{Mn}$ and $\mathrm{Zn}$ ) were selected as they represent the most common trace and toxic metals affecting coastal communities (Roberts et al., 2008). These metals are also essential micronutrients for plants and are not necessarily toxic but many anthropogenic activities increase their natural concentrations causing pollution (Sanz-Lazáro et al., 2012). Additionally, Ambo-Rappe et al. (2011) pointed out that once threshold levels of trace elements are reached, it affects both root cellular structure and photosynthesis. In some areas, seagrasses represent the greatest heavy metal reservoir, and the ecosystem can remobilize metals through litter production and in food chains (Amado Filho et al., 2004). This contrasts with the relative immobilization which occurs in unvegetated sediments (Amado Filho et al., 2004). To understand trace element cycling in seagrasses, it is important to study the accumulation trends in the whole plants followed by further investigation into accumulation patterns among their compartments such as leaves, roots, rhizomes and epiphytes (Sanz-Lazáro et al., 2012).

This study is the first to focus on seagrass trace metal contents in whole plant tissues, seagrass meadows and compare these with unvegetated areas, based on earlier recognition of these metals ( $\mathrm{Cu}, \mathrm{Fe}, \mathrm{Mn}$ and $\mathrm{Zn}$ ) as historical contaminants in Laucala Bay, Fiji (Morrison et al., 2001). H. ovalis, H. pinifolia and H. uninervis were selected for this study because they are common along the Fijian coastlines. Moreover, Short et al. (2014) highlighted that in the tropical Western Pacific region, $H$. ovalis, $H$. pinifolia and $H$. uninervis are considered pioneer species growing rapidly and surviving well in unstable or depositional environments. Similar to other studies, we found significant variation in metal contents with respect to species and site (Table 5). This study demonstrated that trace metal content varied among the three seagrass species, prominently including high Fe content in sediments and whole plant tissue.

Seagrass sediments from Korotogo and Nasese both showed greater Fe and Mn content compared to plant tissues, and similarly, unvegetated areas showed higher content of these two metal elements. In contrast, micronutrient $(\mathrm{Cu}$ and $\mathrm{Zn}$ ) contents were the lowest and least accumulated in all seagrass species and sediments at both sites. $\mathrm{Cu}$ and $\mathrm{Zn}$ are essential for the growth of seagrass and in general, their concentrations are low, i.e., $\leq 10 \mu \mathrm{g} \mathrm{g}^{-1}$ for $\mathrm{Cu}$ and $\leq 30 \mu \mathrm{g} \mathrm{g}{ }^{-1}$ for $\mathrm{Zn}$ (Immaculate et al., 2018). Additionally, sediment contents of $\mathrm{Zn}$ and $\mathrm{Cu}$ at Nasese were lower than tissue contents of all three seagrass species. In contrast, Morrison et al. (2001) reported that intertidal sites at Laucala Bay showed high content of $\mathrm{Cu}$ and $\mathrm{Zn}$ possibly due to pollution from a local industrial area, less than $1 \mathrm{~km}$ upstream from the Vatuwaqa River which discharges effluents into the Bay.

Pratap et al. (2020) reported Zn content in water samples from Laucala Bay ranging between $76.9 \pm 0.9$ to $119.0 \pm 3.0 \mu \mathrm{g} \mathrm{g}^{-1}$, which is well within the ranges reported here for seagrass tissue and sediments. The authors reported a decrease in $\mathrm{Zn}$ content for the area over several years, which may result from a decrease in anthropogenic sources and implementation of an Environmental Management Act (EMA) by the Government of Fiji (Pratap et al., 2020). The contributing source of $\mathrm{Cu}$ and $\mathrm{Zn}$ in the coastal environment could have been from the urbanization and industrialization of these areas (Pratap et al., 2020). The present study assessed $\mathrm{Zn}$ concentrations in sediment and identified it as being available at the third highest level. Our data shows that $\mathrm{Zn}$ was recorded at the highest content in tissues of $H$. uninervis $(52.27 \pm 1.76$ $\mu \mathrm{g} \mathrm{g}^{-1}$ ) at Nasese, while the lowest level was recorded in $H$. pinifolia $\left(22.33 \pm 3.22 \mu \mathrm{g} \mathrm{g}^{-1}\right)$ tissues at Korotogo. The results obtained for $\mathrm{Zn}$ in 
the present study were compared to the results of Mishra et al. (2020) for the same three seagrass species where H. pinifolia $\left(35-69.17 \mu \mathrm{g} \mathrm{g}^{-1}\right.$ ) had accumulated higher Zn content, while $H$. ovalis $\mathrm{Zn}$ content was within this range (Table $\mathrm{S} 4)$.

Mishra et al. (2020) reported that the $\mathrm{Cu}$ content of the seagrass (H. ovalis, $H$. pinifolia and $H$. uninervis) from India varied from 3.79 to $60.83 \mu \mathrm{g} \mathrm{g}^{-1}$ which is comparable to those reported in the three seagrass species in this study ( 8.7 to $20.5 \mu \mathrm{g} \mathrm{g}^{-1}$ ). Nonetheless, the low $\mathrm{Cu}$ and $\mathrm{Zn}$ contents of seagrasses reported in this study, from both study sites, suggest moderate trace metal (Table 3) pollution, and such levels may be considered background levels for a tropical coastal locality. The $\mathrm{Cu}$ and $\mathrm{Zn}$ contents detected reflect that these may be mobilized by human activities, in contrast to $\mathrm{Fe}$ and $\mathrm{Mn}$ which are mainly of lithogenic origin (Serrano et al., 2011).

The results showed that $H$. ovalis $\left(5668 \pm 139.66\right.$ ind. $\left.\mathrm{m}^{-2}\right)$ had a 1.4fold lower shoot density (Table S5) than that of $H$. pinifolia (6450.00 \pm 200.15 ind. $\mathrm{m}^{-2}$ ) and $H$. uninervis $\left(8069.00 \pm 189.99\right.$ ind. $\left.\mathrm{m}^{-2}\right)$. Whole plant biomass of $H$. ovalis $\left(3522.00 \pm 159.22 \mathrm{~g} \mathrm{DW} \mathrm{m}^{-2}\right.$ ) was 3 -fold lower than that of $H$. uninervis $\left(9693.20 \pm 244.86 \mathrm{~g} \mathrm{DW} \mathrm{m}^{-2}\right)$; while $H$. pinifolia was 1.5 -fold lower than that of $H$. uninervis (Table S5). The Fe contents of all three seagrasses sampled in this study were high with H. ovalis accumulating the highest level of $26,137.00 \pm 1322.79 \mu \mathrm{g} \mathrm{g}^{-1}$ at the Korotogo site. Although in general, the plants with higher biomass tend to accumulate higher metals, this seems not to be the case in the present study. This may result from smaller seagrass species such as $H$. ovalis that have thinner roots underlying surface sediments that may allow easier access to elements and a greater surface to volume or biomass ratio compared to larger seagrass species (Duarte et al., 1998).

Furthermore, $H$. ovalis roots are located within the first few centimeters of sediment and are likely to extract Fe more rapidly compared to $H$. pinifolia and $H$. uninervis, which have a more complex root and rhizome network (pers. obs.). Fe content was around 1 to 5 -fold higher in seagrass biomass than in sediments at both sites in this study. The results also show that, of those tested, Fe was the metal element with the greatest absorption in sediments of both vegetated and unvegetated areas. Prange and Dennison (2000) reported Fe as an essential element required by enzymes and proteins during photosynthesis and respiration processes. They suggested that higher Fe content in some plants may cause photosensitivity linked to Fe accumulation in chloroplasts, while Duarte et al. (1995) suggested a minimum of $600 \mathrm{mg} \mathrm{kg}^{-1}$ was required for Fe content to be sufficient for seagrasses. Overall, the seagrasses sampled at the two Fijian sites in this study had an average Fe content of $25,281.60$ and $62,698.33 \mu \mathrm{g} \mathrm{g}^{-1}$, respectively, at Suva and Sigatoka, which are well above the average global values reported for seagrasses (e.g., $412 \mathrm{mg} \mathrm{kg}^{-1}$, Anton et al., 2018). The concentration of Fe obtained in the current study seemed to be more than sufficient.

Moreover, our results are in line with the findings of Pratap et al. (2020) and other studies in the Pacific region (Table 4) who reported high Fe contents in water samples from Laucala Bay (ranging from 47,067 to $68,492 \mu \mathrm{g} \mathrm{g}^{-1}$ ) and sediments. Although the present study did not measure elements in water however, concentration in the water, sediment and seagrass might be different but may be correlated. These authors suggested that the Fe content showed low increases over the past 25 years that could be due to minimal anthropogenic or natural weathering processes in the area. On the other hand, our study also showed that seagrasses at the Korotogo site accumulate more Fe in their tissues than those at Nasese. Similar trend were observed in the whole plant tissues of the three seagrass species reported by Mishra et al. (2020) where Fe content was the highest element (795-1886 $\mu \mathrm{g} \mathrm{g}^{-1}$ ) accumulated in $H$. pinifolia (Table S4). However, Fe content in the present study $\left(7493-26,137 \mu \mathrm{g} \mathrm{g}^{-1}\right)$ was much higher than reported by Mishra et al. (2020); this could be because the uptake of the elements is influenced by their available concentrations in the surrounding sediment.

The highest Mn content was recorded in $H$. uninervis beds $(8.02 \pm$ $1.02 \mu \mathrm{g} \mathrm{g}^{-1}$ ) at Korotogo, however, the overall Mn accumulation seemed to be more in seagrass tissues from Nasese. Patterns of Mn accumulation was reasonably consistent between the samples analyzed, indicating that they all responded similarly and irrespectively of the total Mn content, and thus, may be considered representative of the total metal availability in the environment. Elevated Mn contents in sediments and seagrass biomass have been cited for other seagrass species (Prange and Dennison, 2000). Analysis of the biological concentration factor showed that $H$. ovalis accumulated up to five-fold higher $\mathrm{Cu}$ concentration compared to one-fold for both the Halodule species. Similarly, Fe concentration was found to be one-fold for both Halodule species compared to two-fold for $H$. ovalis. On the other hand, bioaccumulation factor values showed that $H$. ovalis accumulated approximately two and a half times more Mn than the two Halodule species. While, bioaccumulation factor for $H$. ovalis, $H$. pinifolia and $H$. uninervis showed $\mathrm{Zn}$ concentration to be approximately one-fold.

Therefore, the analysis of biological concentration factor led to the conclusion that seagrass $H$. ovalis can be a good bioindicator for some of these metals as pollutants of coastal sediment. Lewis and Devereux (2009) pointed out that Zostera marina and P. oceanica have been recommended as bioindicators of environmental condition on numerous occasions and as agents of phytoremediation due to their bioaccumulation ability. However, the authors suggested that bioaccumulation is affected by the time of collection (growing, nongrowing seasons) and the tissue (above and belowground) analyses (Lewis and Devereux, 2009). Moreover, there is a need to investigate bioaccumulation in these seagrasses during non-growing season and analyze separately above and belowground tissues that were not carried out in the present study. Once a study of biological (leaves, roots and rhizome) has been completed, it may be possible to determine which individual materials are storing most of these metal elements. Globally, there are some toxicity assessment of trace elements on seagrass physiology of H. ovalis (Ambo-Rappe et al., 2011) and H. uninervis (Prange and Dennison, 2000). However in Fiji, trace metal toxicity assessment on seagrass physiology or growth have not been reported therefore, further investigation are needed to provide details and understanding the impacts of these on the plant and coastal environment.

As a result, $\mathrm{Fe}$ and $\mathrm{Mn}$ distributions in sediments and seagrass tissue at both the sites displayed a similar pattern of variation that varied significantly in sediment but not in seagrass tissues (Table 5). The results show that the close relationship between Fe and Mn may result from the two metals having the same source. This implies that Fe and Mn, which are of lithogenic origin, may result from relatively high terrigenous inputs to coastal sediments from local sources such as catchments and surface runoff (Serrano et al., 2011). We found that seagrass species were not $\mathrm{Fe}$ or $\mathrm{Mn}$ deficient, but higher than anticipated content occurred in carbonate sediment because of their lithogenic origin. In contrast, $\mathrm{Cu}$ and $\mathrm{Zn}$, which mobilize through human activities such as urban and industrial effluents, agricultural activity, sewage and boating, were low and reflected a positive correlated pattern. The most obvious explanation for these low levels could be the implementation of an Environmental Management Act (EMA) by the Government of Fiji in 2005 as pointed out by Pratap et al. (2020). Additionally, the interdependency between these metals ( $\mathrm{Fe}$ and $\mathrm{Mn}$; $\mathrm{Cu}$ and $\mathrm{Zn}$ ) means that reduction in the availability of one metal and the simultaneous increase in another may result in uncertainty in predicting responses.

Our results indicate that variation in the trace metal content of within different ecosystems could be due to various land-use activities in the surrounding area, even in different regions of the same ecosystems. While it is not possible at this stage to fully explain this, they do provide a means of guiding between samples metal content. These findings indicate that trace metal contents recorded in vegetated and unvegetated areas may be site-specific, suggesting further investigations should be performed to clarify point source pollution in local areas. Moreover, the surrounding environmental conditions of seagrasses should be controlled to avoid any metal pollution effect (Prange and Dennison, 2000). Therefore, from an environmental management perspective 
there is a need to know which seagrass species are able to accumulate or concentrate particular metals for mitigation of coastal metal pollution. Our study shows that $H$. ovalis has a remarkable ability to take-up and accumulate these metals more efficiently and effectively compared to the other two seagrass species. However, it is worth mentioning that literature reports of growth rate of $H$. uninervis $\left(1.53 \mathrm{~cm} \mathrm{day}^{-1}\right)$ is generally higher than $H$. ovalis $\left(0.69 \mathrm{~cm} \mathrm{day}^{-1}\right)$ as reported by Mishra et al. (2021) and is generally acknowledged of the two genus. It is also noteworthy that $H$. ovalis accumulated up to five-fold higher contents of the four trace metals tested, compared to $H$. pinifolia and $H$. uninervis. This could be because the species has a strong ability to grow clonally, which plays a critical role in its adaptation to various environments (Erftemeijer and Stapel, 1999). Rozaimi et al. (2013) suggested Halophila species invest more energy in rapid clonal propagation, resulting in high turnover rates and Vermaat et al. (1995) indicated that $H$. ovalis is the fastest growing seagrass species in tropical seagrass beds.

Additionally, Prange and Dennison (2000) reported that $H$. ovalis and $H$. spinulosa concentrated more trace metals than Zostera capricorni and $H$. uninervis. Results of the present study concur with this pattern, suggesting that $H$. ovalis is a trace metal accumulator and as a consequence, may be more prone to the toxic effects linked with sequestration of trace metals from the environment that may provide a source of contamination to seagrass consumers (Prange and Dennison, 2000). Ambo-Rappe et al. (2011) observed that the higher concentrations of $\mathrm{Cu}$ inhibited the growth and increased leaf asymmetry of $H$. ovalis. The authors noted that the plant actively takes up $\mathrm{Cu}$; however, increased concentrations may exceed metabolic requirements and result in a toxic impact.

This observation suggests that metal element uptake efficiency may be higher for smaller species, which grow faster and therefore have a greater nutrient demand per unit biomass (Duarte et al., 1998). This also gives an indication that different seagrass species are capable of accumulating metals at different rates from the environment as shown by the two Halodule species in this study. The reason for these differences is unclear; however, factors to consider would be the relative metal availability in unvegetated areas for uptake by seagrass plants i.e., from the water column and sediment that can change from site to site, and which also depends on metal supply (Llagostera et al., 2011). Findings of our study are consistent with this statement in showing this to be true for the three seagrass species analyzed. On the other hand, our results also indicate that sediment resources for trace metal elements are likely to be greater in the uppermost substrate layers where belowground organs of H. ovalis have been observed to grow within $2-5 \mathrm{~cm}$ depth compared to 5-10 cm depth of the two Halodule species (pers. obs.). Moreover, further experimental investigation will help to clarify this phenomenon to increase our understanding of seagrass trace metal accumulation.

Detection of trace metals in the three seagrass species investigated in this study supports previous evidence that seagrasses are able to accumulate trace metals from the marine environment (Prange and Dennison, 2000; Sanz-Lazáro et al., 2012; Govers et al., 2014). Our results show trace metal accumulations within seagrasses appear to be influenced more by the content of biologically available metals within their surroundings, and ensures that seagrasses are reliable sources for metal pollution monitoring in the area. Prange and Dennison (2000) reported that increased rainfall and associated runoff may serve to increase trace metal supply to seagrass habitats, and localized developments can mobilize latent metal sources. Additionally, Waycott et al. (2011) projected that rainfall will increase in the Pacific by $5-20 \%$ as a result of climate change, increasing runoff and supply of toxic chemicals such as herbicide diuron from catchments to seagrass meadows.

Management strategies are therefore needed to consider minimizing potential metal pollution. The presence of metals in both water and sediment has been shown to inhibit the growth of seagrass (Ambo-Rappe et al., 2011). The results of this study demonstrate the potential use of seagrass as a benchmark for measuring and monitoring trace metal contamination in the marine environment. The accumulation capacity of the different seagrass species in Fiji clearly indicates trace element accumulation in seagrass is a species-specific phenomenon and the various seagrass species in Fiji are potential indicators of different trace element concentration in the environment. Likewise, similar trends in content were reported in other seagrasses as discussed above. However, the principal limitation of the present study is that the trends displayed are similar between total biomass and sediment samples collected to measure the elements. Thus, the data does not provide clear indication which tissues (roots, rhizomes and leaf) or species can be used as bioindicators warranting further investigation at local scale.

Seagrasses are often considered useful metal bioindicators and this assessment is validated in this study by comparing, for the first time, metal concentrations found in $H$. ovalis, $H$. pinifolia and $H$. uninervis with those found in sediments in seagrass vegetated and unvegetated areas. Furthermore, this study showed that $H$. ovalis, $H$. pinifolia and H. uninervis might have greater bioaccumulation capacity than previously considered for the four metals studied ( $\mathrm{Cu}, \mathrm{Fe}, \mathrm{Mn}$ and $\mathrm{Zn}$ ). Results suggest that the trace metal contents of seagrass tissues vary with species, endorsing the findings of other studies. Further, our data show the potential before using seagrasses as tools to assess trace metal pollution.

\section{CRediT authorship contribution statement}

Shalini Singh: Conceptualization, Funding acquisition, Data curation, Methodology, Investigation, Formal analysis, Visualization, Writing - original draft, Writing - review \& editing. Monal M. Lal: Supervision, Writing - review \& editing. Paul C. Southgate: Writing review \& editing. Morgan Wairiu: Supervision, Writing - review \& editing. Awnesh Singh: Project administration, Supervision, Writing review \& editing.

\section{Declaration of competing interest}

The authors declare that they have no known competing financial interests or personal relationships that could have appeared to influence the work reported in this paper.

\section{Acknowledgements}

The authors are grateful to the anonymous reviewers whose comments have improved the quality of this manuscript. This research was financially supported by the Pacific Centre for Environment and Sustainable Development, University of the South Pacific, Fiji.

\section{Appendix A. Supplementary data}

Supplementary data to this article can be found online at https://doi. org/10.1016/j.marpolbul.2021.112745.

\section{References}

Ahamad, M.I., Song, J., Sun, H., Wang, X., Mehmood, M.S., Sajid, M., Su, P., Khan, A.J., 2020. Contamination level, ecological risk, and source identification of heavy metals in the hyporheic zone of the Weihe River, China. Int. J. Environ. Res. Public Health 17, 1070. https://doi.org/10.3390/ijerph17031070.

Amado Filho, G.M., Creed, J.C., Andrade, L.R., Pfeiffer, W.C., 2004. Metal accumulation by Halodule wrightii populations. Aquat. Bot. 80 (4), 241-251. https://doi.org/ 10.1016/j.aquabot.2004.07.011.

Ambo-Rappe, R., Lajus, D.L., Schreider, M.J., 2011. Heavy metal impact on growth and leaf asymmetry of seagrass Halophila ovalis. J. Environ. Chem. Ecotoxicol. 3 (6), 149-159.

Anton, A., Hendriks, I.E., Marbà, N., Krause-Jensen, D., Garcias-Bonet, N., Duarte, C.M., 2018. Iron deficiency in seagrasses and macroalgae in the Red Sea is unrelated to latitude and physiological performance. Front. Mar. Sci. 5 (74), 1-14. https://doi. org/10.3389/fmars.2018.00074.

Arikibe, J., Prasad, S., 2020. Determination and comparison of selected heavy metal concentrations in seawater and sediment samples in the coastal area of Suva, Fiji. Mar. Pollut. Bull. 157, e111157 https://doi.org/10.1016/j.marpolbul.2020.111157.

Bonanno, G., Orlando-Bonaca, M., 2018. Trace elements in Mediterranean seagrasses and macroalgae. A review. Sci. Total Environ. 618C, 1151-1158. https://doi.org/ 10.1016/j.scitotenv.2017.09.192. 
Bonanno, G., Veneziano, V., Orlando-Bonaca, M., 2020. Comparative assessment of trace element accumulation and biomonitoring in seaweed Ulva lactuca and seagrass Posidonia oceanica. Sci. Total Environ. 718, e137413 https://doi.org/10.1016/j. scitotenv.2020.137413.

Boutabia-Trea, S., Habachi, W., Bensouilah, M., 2017. Assessment of metallic trace elements using the seagrass Posidonia oceanica and the surface sediment from north eastern of Algeria. Asian J. Biol. Sci. 10, 17-26. https://doi.org/10.3923/ ajbs.2017.17.26.

Bonanno, G., Di Martino, V., 2017. Trace element compartmentation in the seagrass Posidonia oceanica and biomonitoring applications. Mar. Pollut. Bull. 116, 196-203. https://doi.org/10.1016/j.marpolbul.2016.12.081.

Chand, V., Prasad, S., Prasad, R., 2010. Distribution and chemical fractionation of arsenic in surficial sediments of the Lami coastal environment in Fiji. S. Pac. J. Nat. Appl. Sci. 28 (1), 78-81.

Clijsters, H., Van-Assche, F., 1985. Inhibition of photosynthesis by heavy metals. Photosynth. Res. 7, 31-40. https://doi.org/10.1007/BF00032920.

Den Hartog, C., 1970. The Sea-Grasses of the World. North-Holland Publishing Company, Amsterdam.

Deo, R., 2000. The study of heavy metal pollution in Rewa River, Fiji (Master of Science). University of the South Pacific, Suva, Fiji. In: Pratap, A., Mani, F.S., Prasad, S., 2020. Heavy metals contamination and risk assessment in sediments of Laucala Bay, Suva, Fiji. Mar. Pollut. Bull. 156, 111238 https://doi.org/10.1016/j. marpolbul.2020.111238.

Duarte, C.M., Merino, M., Gallegos, M., 1995. Evidence of iron deficiency in seagrasses growing above carbonate sediments. Limnol. Oceanogr. 40, 1153-1158. https://doi. org/10.4319/lo.1995.40.6.1153.

Duarte, C.M., Merino, M., Agawin, N.S.R., Uri, J., Fortes, M.D., Gallegos, M.E., Marba, N., Hemminga, M.A., 1998. Root production and belowground seagrass biomass. Mar. Ecol. Prog. Ser. 171, 97-108. https://doi.org/10.3354/meps171097.

Duarte, C.M., 1999. Seagrass ecology at the turn of the millennium: challenges for the new century. Aquat. Bot. 65, 7-20. https://doi.org/10.1016/S0304-3770(99)000273.

Erftemeijer, P.L.A., Stapel, J., 1999. Primary production of deep-water Halophila ovalis meadows. Aquat. Bot. 65, 71-82.

Gangaiya, P., Tabudravu, J., South, R., Sotheeswaran, S., 2001. Heavy metal contamination of the Lami coastal environment, Fiji. S. Pac. J. Nat. Appl. Sci. 19 (1), 24-29.

Govers, L.L., Lamers, L.P.M., Bouma, T.J., Evgensteyn, J., de Brouwer, J.H.F., Hendricks, A.J., Hujibers, C.M., van Katwijk, M.M., 2014. Seagrasses as indicators for coastal trace metal pollution: a global meta-analysis serving as a benchmark, and a Caribbean case study. Environ. Pollut. 195, 210-217.

Greiner, J.T., McGlathery, K.J., Gunnell, J., McKee, B.A., 2013. Seagrass restoration enhances "blue carbon" sequestration in coastal waters. PLoS One 8 (8), e72469.

Gullström, M., Lyimo, L.D., Dahl, M., Samuelsson, G.S., Eggertsen, M., Anderberg, E., Rasmusson, L.M., Linderholm, H.W., Knudby, A., Bandeira, S., Nordlund, L.M., Bjork, M., 2018. Blue carbon storage in tropical seagrass meadows relates to carbonate stock dynamics, plant-sediment processes, and landscape context: insights from the western indian ocean. Ecosystems 21, 551-566.

Kim, J.H., Kang, J.H., Jang, J.E., Choi, S.K., Kim, M.J., Park, S.R., Lee, H.J., 2017. Population genetic structure of eelgrass (Zostera marina) on the Korean coast: current status and conservation implications for future management. PLoS One 12 (3), e0174105. https://doi.org/10.1371/journal.pone.0174105.

Kuo, J., 2020. Taxonomy of the genus halophila thouars (Hydocharitaceae): a review. Plants 9, e1732. https://doi.org/10.3390/plants9121732.

Immaculate, J.K., Lilly, T.T., Patterson, J., 2018. Macro and micronutrients of seagrass species from Gulf of Mannar, India. MOJ Food Process Technol. 6 (4), 391-398. https://doi.org/10.15406/mojfpt.2018.06.00193.

Lal, M.M., Southgate, P.C., Jerry, D.R., Bosserelle, C., Zenger, K.R., 2016. A parallel population genomic and hydrodynamic approach to fishery management of highlydispersive marine invertebrates: the case of the Fijian black-lip pearl oyster Pinctada margaritifera. PLoS One 11 (8). https://doi.org/10.1371/journal.pone.0161390.

Lewis, M.A., Devereux, R., 2009. Nonnutrient anthropogenic chemicals in seagrass ecosystems: fate and effects. Environ. Toxicol. Chem. 28 (3), 644-661. https://doi. org/10.1897/08-201.1.

Lindsay, W.L., Norvell, W.A., 1978. Development of a DTPA soil test for zinc, iron, copper, and manganese. Soil Sci. Soc. Am. J. 42, 421-428.

Llagostera, I., Pérez, M., Romero, J., 2011. Trace metal content in the seagrass Cymodocea nodosa: differential accumulation in plant organs. Aquat. Bot. 95, 124-128. https://doi.org/10.1016/j.aquabot.2011.04.005.

Maata, M., Singh, S., 2008. Heavy metal pollution in Suva harbor sediments, Fiji. Environ. Chem. Lett. 6 (2), 113-118. https://doi.org/10.1007/s10311-007-0122-1.

McKenzie, L.J., Yoshida, R.L., 2020. Over a decade monitoring Fiji\&apos;s seagrass condition demonstrates resilience to anthropogenic pressures and extreme climate events. Mar. Pollut. Bull. 160, e111636 https://doi.org/10.1016/j. marpolbul.2020.111636.

Mishra, A.K., Khadanga, M.K., Patro, S., Apte, D., 2021. Population Structure of a Newly Recorded (Halodule uninervis) and Native Seagrass (Halophila ovalis) Species From an Intertidal Creek Ecosystem. https://doi.org/10.20944/preprints202103.0392.v1.
Mishra, A.K., Sahoo, R., Samantaray, S.S., Apte, D., 2020. Seagrass Ecosystems of India as Bioindicators of Trace Metals. https://doi.org/10.20944/preprints202011.0377.v1.

Morrison, R., Brown, P., 2003. Trace metals in Fanga'uta lagoon, Kingdom of Tonga. Mar. Pollut. Bull. 46, 146.

Morrison, R.J., Naqasima, M.R., 1999. Fiji's great astrolabe lagoon: baseline study and management issues for a pristine marine environment. Ocean Coast. Manag. 42, 617-636.

Morrison, R.J., Narayan, S.P., Gangaiya, P., 2001. Trace element studies in Laucala Bay, Suva, Fiji. Mar. Pollut. Bull. 42 (5), 397-404. https://doi.org/10.1016/S0025-326X (00)00169-7.

Muller, G., 1969. Index of geoaccumulation in sediments of the Rhine River. Geological. J. $2,108-118$.

Pohler, S.M.L., Collen, J.D., 2006. Aspects of the sedimentology of Laucala Bay and Suva Harbour, Suva. In: Morrison, R.J., Aalbersberg, B. (Eds.), At the Crossroads: Science and Management of Suva Lagoon. University of the South Pacific, Institute of Applied Sciences, Suva, Fiji, pp. 120-141.

Prange, J.A., Dennison, W.C., 2000. Physiological responses of five seagrass species to trace metals. Mar. Pollut. Bull. 40 (7-12), 327-336. https://doi.org/10.1016/S0025326X(00)00126-0.

Prasad, M., Spiers, M., 1978. Comparative study of ashing techniques for the digestion of horticulture plants samples. J. Agric. Food Chem. 26, 824-827.

Pratap, A., Mani, F.S., Prasad, S., 2020. Heavy metals contamination and risk assessment in sediments of Laucala Bay, Suva, Fiji. Mar. Pollut. Bull. 156, 111238 https://doi. org/10.1016/j.marpolbul.2020.111238.

Ralph, P.J., Burchett, M.D., 1998. Photosynthetic response of Halophila ovalis to heavy metal stress. Environ. Pollut. 103, 91-101. https://doi.org/10.1016/S0269-7491 (98)00121-3.

Ralph, P.J., Tomasko, D., Moore, K., Seddon, S., Macinnis-Ng, C.M.O., 2006. Human impacts on seagrasses: eutrophication sedimentation and contamination. In: Larkum, A.W.D., Orth, R.J., Duarte, C. (Eds.), Seagrasses: Biology, Ecology and Conservation. Springer, pp. 567-593.

R Core Team, 2020. R: A language and environment for statistical computing. R Foundation for Statistical Computing, Vienna, Austria. https://www.R-project.org/.

Redfern, F.M., 2006. Heavy metal contamination from landfills in coastal marine sediments: Kiribati and New Zealand. The University of Waikato. In: Pratap, A., Mani, F.S., Prasad, S., 2020. Heavy metals contamination and risk assessment in sediments of Laucala Bay, Suva, Fiji. Mar. Pollut. Bull. 156, 111238 https://doi.org/ 10.1016/j.marpolbul.2020.111238.

Roberts, D.A., Johnston, E.L., Poore, A.G.B., 2008. Contamination of marine biogenic habitats and effects upon associated epifauna. Mar. Pollut. Bull. 56, 1057-1065. https://doi.org/10.1016/j.marpolbul.2008.03.003.

Rozaimi, M., Serrano, O., Lavery, P.S., 2013. Comparison of carbon stores by two morphologically different seagrasses. J. R. Soc. West. Aust. 96, 81-83.

Sanchiz, C., Garcia-Carrascosa, A.M., Pastor, A., 2001. Relationships between sediment physico-chemical characteristics and heavy metal bioaccumulation in Mediterranean soft-bottom macrophytes. Aquat. Bot. 69, 63-73. https://doi.org/10.1016/S03043770(00)00120-0.

Sanz-Lazáro, C., Malea, P., Apostolaki, E.T., Kalantzi, I., Marín, A., Karakassis, I., 2012. The role of the seagrass Posidonia oceanica in the cycling of trace elements. Biogeosciences 9, 2497-2507. https://doi.org/10.5194/bg-9-2497-2012.

Serrano, O., Mateo, M.A., Dueñas-Bohórquez, A., Renom, P., López-Sáez, J.A., Martínez Cortizas, A., 2011. The Posidonia oceanica marine sedimentary record: a holocene archive of heavy metal pollution. Sci. Total Environ. 409, 4831-4840. https://doi. org/10.1016/j.scitotenv.2011.08.001.

Serrano, O., Davis, G., Lavery, P.S., Duarte, C.M., Martinez-Cortizas, A., Mateo, M.A., Masqué, P., Arias-Ortiz, A., Rozaimi, M., Kendrick, G.A., 2016. Reconstruction of centennial-scale fluxes of chemical elements in the australian coastal environment using seagrass archives. Sci. Total Environ. 541, 883-894. https://doi.org/10.1016/ j.scitotenv.2015.09.017.

Short, F.T., Coles, R., Fortes, M.D., Victor, S., Salik, M., Isnain, I., Andrew, J., Seno, A., 2014. Monitoring in the Western Pacific region shows evidence of seagrass decline in line with global trends. Mar. Pollut. Bull. 83 (2), 408-416. https://doi.org/10.1016/ j.marpolbul.2014.03.036.

Singh, S., Southgate, P.C., Lal, M.M., 2019. Morphological plasticity in a fijian seagrass: halophila ovalis subsp. bullosa. Reg. Stud. Mar. Sci. 32, e100809 https://doi.org/ 10.1016/j.rsma.2019.100809.

U.S. EPA, 2004. Guidance on surface soil cleanup at hazardous waste sites: implementing cleanup levels. Available online: https://www.epa.gov/sites/production/files/do cuments/epa_cleanup-may04.pdf (accessed on 12 June 2020).

Vermaat, J., Agawin, N.S., Duarte, C., Marba, N., Uri, J.S., 1995. Meadow maintenance, growth and productivity of a mixed Philippine seagrass bed. Mar. Ecol-Progr. Ser 124, 215-225. https://doi.org/10.3354/meps124215.

Waycott, M., McKenzie, L.J., Mellors, J.E., Ellison, J.C., Sheaves, M.T., Collier, C., Schwarz, A.-M., Webb, A., Johnson, J.E., Payri, C.E., 2011. In: Bell, J.D., Johnson, J. E., Hobday, A.J. (Eds.), Vulnerability of Tropical Pacific Fisheries and Aquaculture to Climate Change. Secretariat of the Pacific Community, Noumea, New Caledonia. 